\title{
Susceptibility of Garden Trees and Shrubs to Armillaria Root Rot
}

\author{
Matthew G. Cromey, ${ }^{1 \dagger}$ Jassy Drakulic, ${ }^{1}$ Elizabeth J. Beal, ${ }^{1}$ Ian A. G. Waghorn, ${ }^{1}$ Joe N. Perry, ${ }^{2}$ and Gerard R. G. Clover ${ }^{1}$ \\ ${ }^{1}$ Royal Horticultural Society, Department of Plant Health, RHS Wisley, Woking, Surrey, GU23 6QB, U.K. \\ ${ }^{2}$ Oaklands Barn, Lug's Lane, Broome, Norfolk NR35 2HT, U.K.
}

Abstract

\begin{abstract}
Armillaria root rot (ARR) is a serious disease of woody plants caused by several species of Armillaria. Armillaria isolates from diagnostic samples received in 2017 were identified by genus- and species-specific PCR and compared with isolates from an earlier survey (2004 to 2007). The results were comparable and, therefore, were combined for further analysis. Three species were identified: Armillaria mellea (83\%), A. gallica (15\%), and A. ostoyae (2\%). Their wide host range makes choice of resistant plants in management of the disease difficult. We used the Royal Horticultural Society diagnostic dataset of ARR records from U.K. gardens to compare the susceptibility of different host genera to the disease. The dataset was compared with an earlier experiment at the University of California. An index-based approach was used to separate genera into three categories: 77 low-index $(<0.99), 37$ medium-index (0.99 to 1.76), and 56 high-index (>1.76) genera were
\end{abstract}

recorded. All three species were associated with both angiosperms and gymnosperms; moreover, A. ostoyae did not show the host preference for gymnosperms that has been reported elsewhere. A. gallica was particularly common on herbaceous perennials and showed a trend to occur on resistant hosts that may be under other stress, supporting its description as an opportunistic pathogen. Four monocotyledons grown as trees or shrubs in U.K. gardens had a very low ARR index according to indices associated with A. mellea and A. ostoyae. Genera in the order Myrtales were almost always low index, while those in the Saxifragales and Fagales were mostly high index. These results provide confidence in the use of host resistance as part of the integrated management of ARR.

Keywords: Armillaria gallica, Armillaria mellea, Armillaria ostoyae, disease index, honey fungus, PCR, resistance
Armillaria root rot (ARR) is a serious disease of woody plants wherever they are grown (Baumgartner et al. 2011). The disease is caused by a range of species of the Basidiomycete genus Armillaria (Fr.) Staude, commonly known as honey fungus. Armillaria spp. have a very wide host range among trees and shrubs (Moore 1959; Raabe 1962). It is likely that most woody plants are susceptible to some degree (Greig et al. 1991), making choice of resistant plants as part of ARR management difficult (Heinzelmann et al. 2019).

Symptoms of ARR are often first observed when upper parts of the plant die. Sometimes this occurs suddenly during periods of hot dry weather and sometimes more gradually, with shoots dying back over the course of several years. The onset of foliar symptoms is typically associated with the presence of subcortical mycelial fans at both the root collar and on the majority of main, lateral roots (Baumgartner et al. 2011). Death of the host results once it can no longer survive on the remaining functional vascular tissue in the roots (Baumgartner et al. 2011). Other signs of infection include rhizomorphs in the soil or over bark surfaces and the appearance of honey-colored basidiomata in the autumn.

Although the effects of ARR in woodlands are sometimes significant, the problem is more serious in parks, gardens, arboreta, and commercial orchards and vineyards, regardless of the Armillaria spp. involved and where the value of each plant is comparatively high (Coetzee et al. 2001; Greig et al. 1991; Travadon et al. 2012). Once Armillaria is present in a garden, it is very difficult to eliminate because it can live saprotrophically on the remains of dead, infected plants and it is difficult to remove all sources of inoculum (infected woody roots left buried in the soil after clearing an infected host)

${ }^{\dagger}$ Corresponding author. M. G. Cromey; matthewcromey@rhs.org.uk

*The $\boldsymbol{e}$-Xtra logo stands for "electronic extra" and indicates that one supplementary table is published online.

The author(s) declare no conflict of interest.

Accepted for publication 12 August 2019.

(C) 2020 The American Phytopathological Society from the soil (Greig et al. 1991). Therefore, evidence of the susceptibility of different garden plants to damage by Armillaria spp. would assist gardeners in making planting choices in high-risk situations. Knowledge of which trees and shrubs possess either resistance (resisting the pathogen, because the level of colonization is kept low) or tolerance (coping with a high level of colonization by the pathogen) would aid in managing the disease (Heinzelmann et al. 2019).

The Royal Horticultural Society (RHS) receives samples from its members for disease diagnosis. Records are held in the RHS database and provide a potentially valuable source of information on Armillaria resistance. It has been the most common disease identified by plant pathologists at the RHS Gardening Advice Service for more than 20 years. Between 2001 and 2018, 18\% of all diagnoses by the RHS were ARR, on 282 tree and shrub genera as well as 12 climbers and a few other perennials. Drakulic et al. (2017) noted that the visibility or relative value of the plants affected would influence the likelihood of a diseased plant sample being sent for diagnosis. Therefore, some adjustment for the popularity of a plant is needed to convert the number of ARR records (AR) on each host to the relative likelihood that a host would be affected by the disease.

Raabe (1966, 1979, 2008) reported on a long-term field experiment in an old orchard area infested with Armillaria spp. at the University of California (UC) Deciduous Field Station in Santa Clara, CA. Plants from 182 genera were monitored for death and for Armillaria infection over a 10 -year period. They were then recorded as resistant (rarely damaged by the fungus), moderately resistant (frequently infected but rarely killed), or susceptible (severely infected and usually killed by the fungus). In the United Kingdom, Greig et al. (1991) (first published in 1921), supplemented by Dickens (1985), prepared a list of trees and shrubs either highly susceptible (frequently killed at any age) or resistant enough to make their planting in an infected area reasonably likely to succeed. It was noted that the rankings depended heavily on the frequency of recorded cases on each host and, therefore, were biased by such factors as frequency of the host.

The ability to predict susceptibility to ARR at the level of plant family or above would further aid in providing planting choices in high-risk situations, such as public and home gardens, where the soil cannot safely be fumigated or the residual roots cannot easily be dug 
out with heavy machinery. It would also provide insight for further work seeking to understand the basis of resistance or susceptibility to infection by Armillaria spp. or resulting dieback and death. Shearer et al. (1998) made some observations on plant families that had particularly high or low proportions of genera being killed by Armillaria infections in coastal dunes in Australia. Other than this study, we were able to find little comment on susceptibility to Armillaria damage above the level of genus in the literature. Further, there are different Armillaria spp. in the Northern Hemisphere.

Historically, the name Armillaria mellea sensu lato has been used to describe what now is known to be over 10 different species (Anderson and Ullrich 1979; Korhonen 1978), meaning we cannot be sure which species were included in the selection of isolates used in the Raabe study, especially in the case of plants that were infected by simply planting them in the ground where inoculum was present in the soil. Five species of Armillaria and two of Desarmillaria (Herink) Koch \& Aime (which were formerly assigned to Armillaria) have been recorded in the United Kingdom (Coetzee et al. 2018; Guillaumin et al. 1993). The subset of Armillaria spp. present in U.K. gardens, however, appears to be more restricted than the full diversity of species present in the United Kingdom. Three species- $A$. mellea sensu stricto (Vahl) P. Kumm, A. gallica Marxm. \& Romagn. and $A$. osotyae (Romagnesi) Herink)-were identified in a 4-year (2004 to 2007) survey of U.K. gardens, the three species representing 84,14 , and $2 \%$ of the total, respectively (Drakulic et al. 2017). A. mellea and A. ostoyae are considered virulent pathogens capable of infecting and causing disease in otherwise healthy hosts, whereas A. gallica is considered to be a relatively weak pathogen, existing preferentially as a saprophyte (Gregory et al. 1991; Guillaumin et al. 1993). In support of this difference in virulence, Drakulic et al. (2017) reported a greater representation of A. mellea and A. ostoyae in gardens where multiple plant types had been affected by the same pathogen species than their abundance overall. It has been suggested that $A$. mellea may be better suited than other species to gardens, due to high disturbance levels and a greater diversity of potential host plants (Drakulic et al. 2017). Associations between $A$. mellea and gardens or cultivated areas were found in surveys of the United Kingdom (Denman et al. 2016; Rishbeth 1982) and Greece (Tsopelas 1999). The growth habit of A. mellea features poor rhizomorph production but, instead, aggressive invasion of healthy hosts and subsequent spread by growth through susceptible roots or from healthy root systems growing into contact with inoculum (Baumgartner and Rizzo 2001). Attempts to eradicate inoculum are often incomplete and new infections develop when replanted hosts inevitably grow into contact with inoculum. Therefore, we hypothesize that the presence of inoculum is continuous over the tenure of a gardener and that Armillaria spp. distributions are unlikely to change, although long-distance movement such as on plants can occur (Coetzee et al. 2001).

Determination of the degree of resistance or tolerance of trees and shrubs to ARR would provide a valuable tool in the integrated management of the disease. The objectives of this study were therefore to (i) develop and validate a list of garden trees and shrubs according to their relative likelihood of damage, (ii) determine any relationship between plant order or clade and susceptibility, and (iii) scrutinize the host preferences Armillaria spp. associated with the disease in U.K. gardens and compare this with other disease environments.

\section{Materials and Methods}

RHS dataset. The RHS operates a diagnostic clinic as a part of an advisory service for its 500,000 members. RHS records are from U.K. gardens and represent the only large database of AR in gardens that we are aware of. Data relevant to this study include the numbers of inquiries on each genus to the RHS advisory service and the number of confirmed ARR diagnoses. As a popularity measure, we have used the total inquiries (TE) to RHS Advisory on each genus between 1 January 2007 and 31 December 2018: 12 years (the period this information is available for). The TE measure includes inquiries on all aspects of the plant in gardens, including identification, horticulture, and plant health. The number of AR on each host genus was recorded between 1 January 1997 and 31 December 2018: 22 years. The TE for each genus was used to normalize the AR, and compared with the original AR to determine whether AR provides a useful measure of the likelihood of damage due to Armillaria infection.

The Raabe experiment. As far as we are aware, the only largescale test to determine the resistance of different host plants to Armillaria spp. was done at the UC Deciduous Field Station, which used to be in Santa Clara, CA, U.S.A. (Raabe 1966, 1979, 2008). Therefore, we have used the results of this experiment to compare with the RHS dataset. Details of the experiment are not readily available; thus, information on the methods, given by Raabe (1966, 2008), is presented here as follows:

Tests at Santa Clara began in 1929, although information about procedures before 1952 is not available. All plants tested since 1952 were planted in soil where inoculum was present from susceptible plants that previously died of ARR. In addition, two 6- to 8-in. pieces of woody branch material colonized by the fungus in the laboratory were put next to the root system at the time of planting to make sure that the fungus was present. Isolates inoculated to these pieces were selected from plants that died of ARR and, thus, were assumed to be virulent. Furthermore, a number of different isolates were used as inoculum, to represent the range of virulence in what was thought to be a single Armillaria spp. at the time (A. mellea). Ten plants of each species were tested in a plot. Following planting, plants were monitored periodically and dead plants, particularly those with symptoms and signs of ARR, were recorded. After 10 years, all remaining plants were pulled and their root systems were rated as to the level of colonization. The plants listed in the reports are divided into three groups. Those listed as resistant (R) were rarely damaged by the fungus. Those listed as moderately resistant (MR) frequently became infected but rarely were killed by the fungus. Those listed as susceptible (S) were severely infected and usually killed by the fungus.

No quantitative information was presented in the reports (Raabe 1979, 2008). Most genera included a single entry, although some (35\%) were represented by multiple species, subspecies, or cultivars. Where ratings were inconsistent (usually R-MR or MR-S), they were recorded for the purposes of this study as R (mostly resistant), $\mathrm{S}$ (mostly susceptible), or MR (distributed across the categories).

Comparison between RHS data and the Raabe experiment. The first step was to make a graphical comparison of hosts appearing in both the Raabe experiment and the RHS database. The evaluation was restricted to trees and shrubs grown outdoors in the ground in the United Kingdom. This is because plants primarily grown in pots, grown indoors, or usually as annuals are unlikely to be exposed to Armillaria in the United Kingdom. The number of records was plotted against the number of inquiries for each genus, with each point coded as $\mathrm{R}, \mathrm{MR}$, or $\mathrm{S}$ according to the Raabe experiment Raabe (1979, 2008).

Initial examination of the plots indicated that angiosperms and gymnosperms needed to be considered separately because the relationship between our data and the Raabe ratings was clearly different for the two. Any relationship between Raabe ratings and our data broke down for genera with fewer than 100 TE in the RHS dataset, probably because a small change in number of AR will have a large effect on the relationship between TE and AR. Therefore, the analysis used data for the 87 genera in Raabe $(1979,2008)$ with more than 100 RHS inquiries.

Values of TE and AR were transformed logarithmically to new variables $x$ and $y$, where $x=\log _{10}(\mathrm{TE}+1)$ and $y=\log _{10}(\mathrm{AR}+1)$. The transformed variables $x$ and $y$ were plotted against one another, where the points represented genera categorized by Raabe (1979, 2008) as R, MR, or S to ARR. Points for which $x<2$ (i.e., TE < $100)$ were excluded. Three linear regression models of transformed AR $(y)$ on RHS TE $(x)$ were compared for the best fit: a single line through all three Raabe resistance categories, three parallel lines allowing the intercept to vary with resistance category, and three separate lines allowing both slope and intercept to vary with category. This analysis was performed using GENSTAT, 16th edition (VSN International 2013). Discrimination between models was by standard 
partial $F$ tests with two degrees of freedom (Hawes et al. 2003; Perry 1982).

ARR index. An ARR index was developed from RHS data for each genus. Values of ARR were divided by TE (as a way to balance different genera for popularity), then multiplied by 100 , providing a weighted index for each genus.

Relationship between plant taxonomic group and ARR index or Armillaria spp. Angiosperm genera were allocated to family, order, and clade according to the Angiosperm Phylogeny Group (2016). There were relatively few gymnosperms; thus, these were treated as a single group.

The relationships between taxonomic position of the host and ARR index or associated Armillaria spp. were examined. Median, minimum, maximum, and first and third quartile for ARR indices for genera in each taxonomic group were calculated. The number of host genera, in each ARR index group or Raabe rating (Raabe $1979,2008)$ were recorded, along with the number of isolations of each Armillaria spp., from each host taxonomic group.

Finally, $\chi^{2}$ analyses were performed for comparison of the proportion of genera in taxonomic groups assigned to each resistance category, as well as for the proportion of Armillaria spp. in each taxonomic group. Differences worthy of note between observed and expected outcomes were defined as $(o-e)^{2} / e>2$, where $o$ is the observed count and $e$ the expected.

Isolation of Armillaria spp. Isolations were attempted for all ARR diagnoses made by the RHS advisory service for the calendar year 2017. Samples comprising infected bark and root material were dissected into roughly $1-\mathrm{cm}^{3}$ pieces taken from six representative parts of the specimen. The prepared portions were surface sterilized in diluted domestic bleach (30\% [vol/vol]) and rinsed in sterile distilled water for $30 \mathrm{~s}$ each before being plated onto JJG media (1\% malt extract agar [MEA] amended with penicillin at $50 \mathrm{mg} \mathrm{liter}^{-1}$, streptomycin sulfate at $50 \mathrm{mg}$ liter $^{-1}$, polymyxin at $25 \mathrm{mg} \mathrm{liter}^{-1}$, and $23 \%$ thiabendazole at $1 \mathrm{mg} \mathrm{liter}^{-1}$ ). After 3 days of incubation in the dark at $23^{\circ} \mathrm{C}$, plates were assessed for Armillaria growth, which was then subcultured onto fresh JJG media. After 2 to 3 weeks, the isolates were subcultured onto $1 \%$ MEA and, after 6 to 8 weeks, were used to obtain pure cultures for DNA extraction.

Identification of Armillaria spp. Species identification followed the methods used in the previous study of samples between 2004 and 2007 (Drakulic et al. 2017). Surface mycelium was scraped from plates using a sterile pipette tip, and DNA was extracted using a DNeasy Plant Minikit according to the manufacturer's instructions (Qiagen, Hilden, Germany). Genus-specific PCR was performed on all samples, followed by species-specific PCR for the three species previously found in gardens (A. mellea, A. gallica, and A. ostoyae). Primer pair ArmEF $1 \alpha$ FOR/ArmEF $1 \alpha$ REV was used for genus-specific PCR, and Amel-F165/Amel-R401, Agal-F123/Agal-R342, and Aost-F102/ Aost-R341 for assays specific for A. mellea, A. gallica, and A. ostoyae, respectively (Mulholland et al. 2012). PCR mixtures of $20 \mu \mathrm{l} \mathrm{com-}$ prised BioMix Red mastermix (Bioline Reagents Ltd.), $0.5 \mathrm{nM}$ each forward and reverse primer, and $1 \mu l$ of template DNA. For Armillaria genus-specific assays, the thermocycling program used was as follows: $95^{\circ} \mathrm{C}$ for $5 \mathrm{~min} ; 35$ cycles of $94^{\circ} \mathrm{C}$ for $30 \mathrm{~s}, 58^{\circ} \mathrm{C}$ for $30 \mathrm{~s}$, and $72^{\circ} \mathrm{C}$ for $1 \mathrm{~min}$; and $72^{\circ} \mathrm{C}$ for $7 \mathrm{~min}$. For the species-specific assays the program was the same, except a $55^{\circ} \mathrm{C}$ annealing temperature was used. PCR products were run on $1.5 \%$ Tris-borate-EDTA gels and visualized under UV light (Bio-Rad Gel Doc 1000).

\section{Results}

Armillaria spp. in U.K. gardens. In the current (2017) survey, 117 isolates were identified to species level from 52 host genera at 97 locations (Table 1). Most isolates were A. mellea. A. gallica was much less common, whereas $A$. ostoyae was infrequently isolated. The close similarity in proportions between the current survey and the earlier 2004-to-2007 survey indicates that there is no difference in species composition over this timescale. The results were compared with $\chi^{2}$ analysis and, with $P=0.34$, it was concluded that the data were similar enough to combine them to make one, more substantial dataset.
The combined dataset features 117 host genera, plus a number of isolates from unspecified conifers, representing 593 U.K. locations. There were 82 sites with multiple plant deaths, 70 of which were infected with a single Armillaria sp., of which $10 \%(n=7)$ were $A$. gallica, $88.6 \%(n=62)$ A. mellea, and $1.4 \%(n=1)$ A. ostoyae. Fourteen sites had more than one species present. Apart from one large public garden (RHS Wisley) that had all three species, all other instances comprised coincidence of A. mellea and A. gallica. Two species (always $A$. mellea and A. gallica) were isolated from a single sample on four occasions, once each on Euonymous L., Viburnum L., Rhododendron L., and x Cupressocyparis leylandii A. B. Jacks \& Dallim.

Use of raw data to assess susceptibility. Examination of the database indicates that the number of AR on each host genus is determined by both its susceptibility to ARR and by its popularity in gardens. AR was compared with TE and other parameters on that host for two pairs of examples (Table 2). Cornus L. and Laburnum Fabr. have a similar AR (36 and 35, respectively), but Cornus had six times the TE as Laburnum as well as many more available cultivars and suppliers. Similarly, Magnolia L. and Ceanothus L. have 61 and $59 \mathrm{AR}$, respectively, but differ markedly in TE and numbers of cultivars and suppliers. The genera Cornus and Magnolia are reported to be resistant to ARR, whereas Laburnum and Ceanothus are reported to be susceptible.

Comparing the RHS dataset with the Raabe experiment: Angiosperms. The RHS dataset was compared with the ratings in the Raabe experiment (Raabe 1979, 2008). The regressions showed that there was a linear relationship between $y$ and $x\left(\mathrm{~F}_{1,85}=160, P<\right.$ $0.001)$, that there was no need for three separate lines $\left(\mathrm{F}_{2,81}=1.91\right.$, $P>0.05)$, and that the best-fitting model was three parallel lines with separate intercepts $\left(\mathrm{F}_{2,88}=13.5, P<0.001\right)$ and the same slope (Fig. 1). The parallel nature of the best-fitting model supports the index-based approach for RHS data; the index is highly associated with the Raabe $(1979,2008)$ categorization.

Furthermore, the estimated slope (1.0038) is so close to unity that it can be assumed that the ARR index behaves in a densityindependent fashion (i.e., it is a stable constant over the genera concerned, whatever their degree of popularity in gardens). This is because the number of AR and the TE increase with each other linearly, in a proportional relationship (i.e., $\mathrm{AR}=a \times \mathrm{TE}$ ), where $a$ is some constant.

- For the $\mathrm{S}$ category, the fitted relationship is $y=-1.613+1.0095 x$, and the estimated constant $a$ is 0.0244 , corresponding to an ARR index of $100 a$ (i.e., 2.44).

Table 1. Armillaria spp. composition in U.K. gardens in 2004 to 2007 and 2017

\begin{tabular}{|c|c|c|c|}
\hline \multirow[b]{2}{*}{ Time period } & \multicolumn{3}{|c|}{$\begin{array}{c}\text { Percentage of isolations in each time period } \\
\text { (number) }\end{array}$} \\
\hline & Armillaria mellea & A. gallica & A. ostoyae \\
\hline 2004-2007 & 84 (470) & $14(80)$ & $2(13)$ \\
\hline 2017 & $81(95)$ & $18(21)$ & $1(1)$ \\
\hline Total & $83(565)$ & 15 (101) & $2(14)$ \\
\hline
\end{tabular}

Table 2. Comparison of number of Armillaria root rot records (AR) and host popularity as measured by total RHS inquiries (TE) in U.K. gardens, number of cultivars available, and number of suppliers for two pairs of hosts and their reported susceptibility to Armillaria root rot

\begin{tabular}{lcrccc}
\hline Host genera & AR & \multicolumn{1}{c}{ TE } & $\begin{array}{c}\text { Number of } \\
\text { cultivars }^{\mathbf{a}}\end{array}$ & $\begin{array}{c}\text { Number of } \\
\text { suppliers }^{\mathbf{a}}\end{array}$ & $\begin{array}{c}\text { Reported } \\
\text { susceptibility }^{\mathbf{b}}\end{array}$ \\
\hline Cornus & 36 & 3,611 & 274 & 138 & Resistant \\
Laburnum & 35 & 608 & 9 & 50 & Susceptible \\
Magnolia & 61 & 5,881 & 491 & 112 & Resistant \\
Ceanothus & 59 & 1,644 & 55 & 83 & Susceptible \\
\hline Cubey & & & & &
\end{tabular}

a Cubey et al. (2019).

b Raabe experiment (Raabe 1979, 2008). 
- For the MR category, the relationship is $y=-1.896+1.0095 x$, and the estimated constant $a$ is 0.0127 , corresponding to an ARR index of $100 a$ (i.e., 1.27).

- For the R category, the relationship is $y=-2.112+1.0095 x$, and the estimated constant $a$ is 0.0077 , corresponding to an ARR index of $100 a$ (i.e., 0.77).

Comparing RHS data with the categories of Raabe $(1979,2008)$ requires the establishment of a set of thresholds for the RHS data. The threshold between $\mathrm{S}$ and MR was determined by calculating the geometric mean of the relevant ARR indices above, giving $\sqrt{ }(1.27 \times 2.44)=1.760$. The threshold between MR and $\mathrm{R}$ was determined by calculating the geometric mean of the relevant ARR indices above, giving $\sqrt{(0.77 \times 1.27)}=0.989$.

Therefore, the thresholds derived were as follows:

- Group 1: Low index (rarely affected, equivalent to R category); genera with an ARR index less than 0.99;

- Group 2: Medium index (sometimes affected, equivalent to the MR category); genera with ARR index from 0.99 to 1.76 ;

- Group 3: High index (frequently attacked, equivalent to the $\mathrm{S}$ category; genera with an ARR index greater than 1.76.

In group 1, there were 37 genera with an index less than $0.99 ; 22$ were listed in the Raabe experiment as R (59\%), 10 as MR (27\%), and $5(14 \%)$ as S. In group 2, there were 19 genera with an ARR index from 0.99 to 1.76 ; 6 were listed in the Raabe experiment as $\mathrm{R}$ $(32 \%), 10$ as MR (53\%), and $3(16 \%)$ as S. In group 3, there were 31 genera with an ARR index greater than 1.76; 16 were listed in the Raabe experiment as S (52\%), 10 as MR (32\%), and 5 as R (16\%).

Comparing the RHS dataset with the Raabe experiment: Gymnosperms. The RHS database includes 15 gymnosperms with $100+$ inquiries, 8 of which had an index of over 1.76 and 4 an index between 0.99 and 1.76. The three low-index genera were Taxus L. (0.42), Cryptomeria D. Don (0.98), and Ginkgo L. (0.74). The susceptibility ratings of gymnosperms in the Raabe experiment were compared with ARR indices for genera with 100+ TE (Table 3). Indices were largely unrelated to the ratings from the Raabe experiment, where most genera were categorized as resistant to ARR and only one as susceptible.

Comparing the RHS dataset with previous U.K. records. The RHS dataset was compared graphically with two related U.K. lists (Dickens 1985; Greig et al. 1991) of angiosperm and gymnosperm

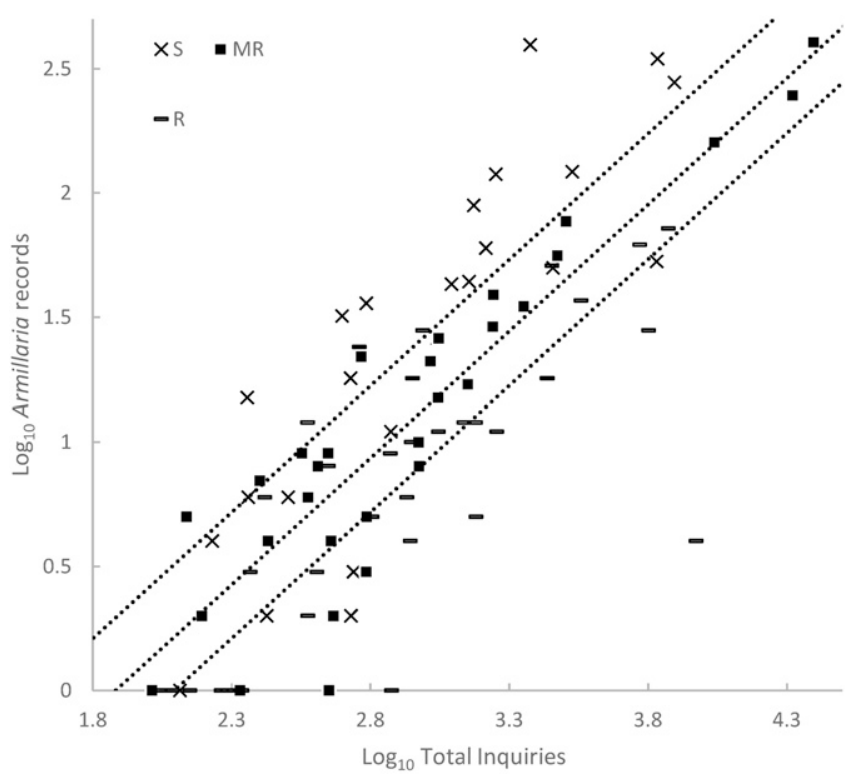

Fig. 1. Fitted and observed relationships between Armillaria root rot records $\left[\log _{10}(A R\right.$ $+1)$ ] versus total inquiries $\left[\log _{10}(T E+1)\right]$, with three parallel fitted lines (line $S$ above, line $M$ in the middle, line $R$ below) for angiosperm genera reported by Raabe (1979, 2008) as susceptible (S), moderately resistant (MR), or resistant (R). genera recorded as notably resistant or notably susceptible to ARR Examination of the plots (results not presented) suggests that the R or $\mathrm{S}$ ratings were strongly skewed by the popularity of plants and, therefore, the comparison was taken no further.

Genera with especially low or high ARR indices. Genera with particularly low or high indices were examined further (Table 4). All four monocotyledons were in the low-index group, as were both genera in the order Buxales. In all, 12 of 17 genera with no AR in the RHS database are recorded as hosts in the literature while 5 (all shrubs) do not appear in any host lists that we are aware of. Four of these were recorded as $\mathrm{R}$ by Raabe.

Sixteen genera had an index of 4+. These included four gymnosperms. Three of seven genera in the family Oleaceae (including Ligustrum L.) were included. Two of six genera in the family Caprifoliaceae were included, although the other four genera were in the low-index group, including one with an ARR index of 0.00 .

Susceptibility of host genera to ARR and associated Armillaria spp. The 155 angiosperm genera of trees and shrubs with 100+ TE were placed into groups according to their ARR index (Table 5). The most common category was the low-index group ( $48 \%$ of genera). The same criteria were used for the 15 gymnosperm genera with 100+ TE.

The majority of Armillaria isolates were obtained from host genera in the high-index group. Relatively few were obtained from low-index genera (Table 5). A. mellea was the most common species isolated from genera in all categories.

There were no strong differences in species composition of isolates from the three angiosperm resistance categories, although there was a trend for A. gallica to occur on resistant plants more often than would be expected (Table 5). The overall $\chi^{2}$ analysis for angiosperms was highly significant, due entirely to abundance of $A$. gallica and $A$. ostoyae isolates from genera of unknown resistance (trees and shrubs with $\mathrm{TE}<100$ as well climbers and herbaceous perennials).

The genera in the three ARR index categories are summarized in Table 6. They include all trees and shrubs in the RHS database with at least 100 TE These were supplemented by six genera with less than 100 TE but where the index is in agreement with the Raabe rating.

Susceptibility of Prunus spp. and types. With 403 Armillaria records, and many (59\%) of the inquiries specifying species or use, we were able to examine the genus Prunus L. in more detail (Table 7). In general, the ARR index for ornamental Prunus spp. was higher than for fruiting Prunus spp., although both fell within the medium index group. Cherry (which include several Prunus spp.) had the highest ARR index. Prunus armeniaca L. and P. persica (L.) Batsch had indices in the low-index group. The two evergreen ornamental Prunus spp. P. laurocerasus L. and P. lusitanica L. differed, having indices of 1.09 and 2.01, respectively. The majority of Armillaria isolates obtained from Prunus spp. were identified as A. mellea, regardless of Prunus sp. or use.

Susceptibility of host family, order, or clade to ARR and associated Armillaria spp. Relationships between the ARR index and host plant taxonomic group were examined (Tables 8 and 9). The same exercise was done for the three resistance categories in Raabe $(1979,2008)$ and notable similarities or differences are detailed here.

The median gymnosperm index was over twice that of the angiosperms (Table 8). Most of the gymnosperm genera were in the highindex group. (Table 9). This is in contrast to the Raabe experiment,

Table 3. Numbers of gymnosperm genera reported to be resistant (R), moderately resistant (MR), or susceptible (S) in each Armillaria root rot (ARR) index category

\begin{tabular}{lccc}
\hline & \multicolumn{3}{c}{ Reported resistance $^{\mathbf{a}}$} \\
\cline { 2 - 4 } ARR index $^{\mathbf{b}}$ & $\mathbf{R}$ & $\mathbf{M R}$ & $\mathbf{S}$ \\
\hline 0.00 to 0.99 & 2 & 0 & 0 \\
0.99 to 1.76 & 0 & 0 & 0 \\
$1.76+$ & 5 & 3 & 1 \\
\hline
\end{tabular}

${ }^{a}$ Raabe $(1979,2008)$.

b Royal Horticultural Society database, total inquiries 100+. 
where most gymnosperms were classified as R. Proportions of angiosperm genera in the three resistance categories were similar in the RHS and Raabe datasets.

The median indices differed between the three main clades of angiosperms (Table 8). Magnolid and Monocotyledon medians were considerably lower than those of the Eudicots. Patterns of R and S angiosperm genera were also similar between the two studies at the level of clade.

Differences in median index were also seen within the Eudicot subclades (Table 8 ). Superrosids had by far the highest median index whereas Asterids and subclade Eudicots had low median indices, although the highest genus index (Ligustrum, 16.6) was a member of the Asterids. Substantially more Superrosids than expected were in the high-index group, while none were in low index (Table 9). There was some evidence that Rosids were less likely than Asterids to be in the low-index group, although the difference was not significant.

Some differences in median index were apparent between Eudicot orders (Table 8). The median index of the Saxifragales was considerably higher than any other order. The median index in the Myrtales was lowest among the Eudicot orders. The family Rosaceae had a higher median index than that of the other families in the order Rosales (Table 8). Similarly, within the order Lamiales, the Oleaceae had a high median index compared with other Lamiales families. The highest-index genus (Ligustrum, 16.6) was in the Oleaceae. Differences in categorization between Eudicot orders were largely in line with the comparison of median index (Table 9). Saxifragales and Fagales genera were substantially less often in the low-index group than expected. Myrtales genera were substantially more often in the low-index group than expected, while the Ericales were more often in the low-index group than expected.

A. mellea was the most common species on both gymnosperms and angiosperms (Table 9). A. gallica and A. ostoyae were recorded on both groups but at much lower frequencies, especially A. ostoyae.

Few isolates were obtained from the angiosperm clades Magnolids and Monocotyledons, both of which have a high proportion of

Table 5. Percentage of host genera and Armillaria spp. isolations in each Armillaria root rot index category

\begin{tabular}{|c|c|c|c|c|}
\hline \multirow[b]{2}{*}{ Index $^{a}$} & \multicolumn{4}{|c|}{ Percentage in category (number) } \\
\hline & Host genera & Armillaria mellea & A. gallica & A. ostoyae \\
\hline \multicolumn{5}{|l|}{ Angiosperms } \\
\hline$<0.99$ & $47.7(74)$ & $81.8(45)$ & $18.2(10)$ & $0.0(0)$ \\
\hline 0.99 to 1.76 & $21.3(33)$ & $86.9(179)$ & $12.1(25)$ & $1.0(2)^{\mathrm{b}}$ \\
\hline$>1.76$ & $31.0(48)$ & $82.4(272)$ & $15.5(51)$ & $2.1(7)$ \\
\hline Unknown & $\ldots$ & $60.5(20)$ & $28.9(10)^{\mathrm{b}}$ & $10.4(4)^{\mathrm{c}}$ \\
\hline \multicolumn{5}{|l|}{ Gymnosperms } \\
\hline$<0.99$ & $20.0(3)$ & $66.7(2)$ & $33.3(1)$ & $0.0(0)$ \\
\hline 0.99 to 1.76 & 26.7 (4) & $100(5)$ & $0.0(0)$ & $0.0(0)$ \\
\hline$>1.76$ & $53.3(8)$ & $90.9(30)$ & $9.1(3)$ & $0.0(0)$ \\
\hline Unknown & $\ldots$ & $88.9(8)$ & $0.0(0)$ & $11.1(1)$ \\
\hline
\end{tabular}

Table 4. Host genera with Armillaria root rot index below 0.10 or above $4.00^{\mathrm{a}}$

\begin{tabular}{|c|c|c|c|c|c|c|c|}
\hline Genus & Index & $\mathbf{A R}$ & TE & Clade & Order & Family & Raabe $^{b}$ \\
\hline Ailanthus & 0.00 & 0 & 109 & Rosids & Sapindales & Simaroubaceae & $\mathrm{R}$ \\
\hline Albizia & 0.00 & 0 & 213 & Rosids & Fabales & Fabaceae & $\mathrm{S}$ \\
\hline Callicarpa & 0.00 & 0 & 182 & Asterids & Lamiales & Lamiaceae & $\mathrm{R}$ \\
\hline Carpenteria & 0.00 & 0 & 161 & Asterids & Cornales & Hydrangeaceae & $\mathrm{R}$ \\
\hline Catalpa & 0.00 & 0 & 750 & Asterids & Lamiales & Bignoniaceae & $\mathrm{R}$ \\
\hline Chamaerops & 0.00 & 0 & 121 & Monocotyledons & Arecales & Arecaceae & $\mathrm{R}$ \\
\hline Chimonanthus & 0.00 & 0 & 141 & Magnolids & Laurales & Calycanthaceae & M \\
\hline Erica & 0.00 & 0 & 446 & Asterids & Ericales & Ericaceae & M \\
\hline Lagerstroemia & 0.00 & 0 & 102 & Rosids & Myrtales & Lythraceae & M \\
\hline Leptospermum & 0.00 & 0 & 129 & Rosids & Myrtales & Myrtaceae & $\mathrm{S}$ \\
\hline Phlomis & 0.00 & 0 & 216 & Asterids & Lamiales & Lamiaceae & $\mathrm{R}$ \\
\hline Phormium & 0.00 & 0 & 952 & Monocotyledons & Asparagales & Asphodelaceae & NA \\
\hline Rhamnus & 0.00 & 0 & 243 & Rosids & Rosales & Rhamnaceae & NA \\
\hline Sarcococca & 0.00 & 0 & 850 & Eudicots & Buxales & Buxaceae & NA \\
\hline Sophora & 0.00 & 0 & 192 & Rosids & Fabales & Fabaceae & $\mathrm{R}$ \\
\hline Symphoricarpos & 0.00 & 0 & 140 & Asterids & Dipsacales & Caprifoliaceae & $\mathrm{R}$ \\
\hline Vaccinium & 0.00 & 0 & 1,348 & Asterids & Ericales & Ericaceae & NA \\
\hline Buxus & 0.03 & 3 & 9,406 & Eudicots & Buxales & Buxaceae & $\mathrm{R}$ \\
\hline Bambusa & 0.04 & 1 & 2,623 & Monocotyledons & Poales & Poaceae & NA \\
\hline Cordyline & 0.08 & 1 & 1,319 & Monocotyledons & Asparagales & Asparagaceae & NA \\
\hline Liquidamber & 4.01 & 23 & 574 & Superrosids & Saxifragales & Hamamelidaceae & $\mathrm{R}$ \\
\hline Thuja & 4.07 & 29 & 712 & Gymnosperm & $\ldots$ & $\ldots$ & $\mathrm{S}$ \\
\hline Juglans & 4.41 & 49 & 1,111 & Rosids & Fagales & Juglandaceae & NA \\
\hline Salix & 4.87 & 165 & 3,390 & Rosids & Malpighiales & Salicaceae & NA \\
\hline Viburnum & 5.07 & 346 & 6,828 & Asterids & Dipsacales & Caprifoliaceae & $\mathrm{S}$ \\
\hline Laburnum & 5.76 & 35 & 608 & Rosids & Fabales & Fabaceae & $\mathrm{S}$ \\
\hline Cotoneaster & 5.93 & 88 & 1,485 & Rosids & Rosales & Rosaceae & $\mathrm{S}$ \\
\hline$x$ Cuprocyparis & 6.17 & 127 & 2,057 & Gymnosperm & $\ldots$ & $\ldots$ & $\mathrm{R}$ \\
\hline Cercidiphyllum & 6.19 & 14 & 226 & Superrosids & Saxifragales & Cercidiphyllaceae & $\mathrm{S}$ \\
\hline Weigela & 6.24 & 31 & 497 & Asterids & Dipsacales & Caprifoliaceae & $\mathrm{S}$ \\
\hline Syringa & 6.63 & 118 & 1781 & Asterids & Lamiales & Oleaceae & $\mathrm{S}$ \\
\hline Forsythia & 6.64 & 31 & 467 & Asterids & Lamiales & Oleaceae & NA \\
\hline Sorbus & 6.84 & 158 & 2,311 & Rosids & Rosales & Rosaceae & NA \\
\hline Metasequoia & 8.11 & 9 & 111 & Gymnosperm & $\ldots$ & $\ldots$ & $\mathrm{R}$ \\
\hline Cedrus & 8.60 & 65 & 756 & Gymnosperm & $\ldots$ & $\ldots$ & NA \\
\hline Ligustrum & 16.59 & 394 & 2,375 & Asterids & Lamiales & Oleaceae & $\mathrm{S}$ \\
\hline
\end{tabular}

a $\mathrm{AR}=$ Armillaria root rot records and $\mathrm{TE}=$ total inquiries.

b Raabe experiment (Raabe 1979, 2008): $\mathrm{R}=$ resistant, $\mathrm{MR}=$ moderately resistant, $\mathrm{S}=$ susceptible, and NA = not assessed. 
Table 6. Summary of Armillaria root rot (ARR) records ${ }^{\mathrm{a}}$

\begin{tabular}{|c|c|c|c|c|}
\hline Host genera $^{b}$ & $\mathbf{A R}$ & TE & Index & Raabe $^{c}$ \\
\hline \multicolumn{5}{|l|}{ Low ARR index } \\
\hline Abelia & 4 & 610 & 0.66 & MR \\
\hline Abutilon & 1 & 536 & 0.19 & $\mathrm{~S}$ \\
\hline Acacia & 11 & 1,370 & 0.80 & $\mathrm{R}$ \\
\hline Ailanthus & 0 & 109 & 0.00 & $\mathrm{R}$ \\
\hline Akebia & 2 & 270 & 0.74 & NA \\
\hline Albizia & 0 & 213 & 0.00 & $\mathrm{~S}$ \\
\hline Arbutus & 9 & 940 & 0.96 & MR \\
\hline Bambusa & 1 & 2,623 & 0.04 & NA \\
\hline Buxus & 3 & 9,406 & 0.03 & $\mathrm{R}$ \\
\hline Caesalpinia $^{\mathrm{d}}$ & 0 & 33 & 0.00 & $\mathrm{R}$ \\
\hline Callicarpa & 0 & 182 & 0.00 & $\mathrm{R}$ \\
\hline Callistemon & 2 & 548 & 0.36 & $\mathrm{~S}$ \\
\hline Calluna & 1 & 126 & 0.79 & NA \\
\hline Calycanthus $^{\mathrm{d}}$ & 0 & 63 & 0.00 & $\mathrm{R}$ \\
\hline Camellia & 35 & 7,637 & 0.46 & NA \\
\hline Carpenteria & 0 & 161 & 0.00 & $\mathrm{R}$ \\
\hline Catalpa & 0 & 750 & 0.00 & $\mathrm{R}$ \\
\hline Ceratostigma & 1 & 137 & 0.73 & NA \\
\hline Chaenomeles & 4 & 610 & 0.66 & $\mathrm{R}$ \\
\hline Chamaerops & 0 & 121 & 0.00 & $\mathrm{R}$ \\
\hline Chimonanthus & 0 & 141 & 0.00 & MR \\
\hline Clerodendrum & 2 & 404 & 0.50 & $\mathrm{R}$ \\
\hline Convolvulus & 1 & 407 & 0.25 & NA \\
\hline Cordyline & 1 & 1,319 & 0.08 & NA \\
\hline Coronilla & 1 & 136 & 0.74 & NA \\
\hline Cotinus & 10 & 1,108 & 0.90 & $\mathrm{R}$ \\
\hline Cryptomeria & 2 & 205 & 0.98 & $\mathrm{R}$ \\
\hline Daphne & 25 & 2,570 & 0.97 & NA \\
\hline Diospyros $^{\mathrm{d}}$ & 0 & 25 & 0.00 & $\mathrm{R}$ \\
\hline Erica & 0 & 446 & 0.00 & MR \\
\hline Eriobotrya & 3 & 333 & 0.90 & NA \\
\hline Erythrina $^{\mathrm{d}}$ & 0 & 33 & 0.00 & $\mathrm{R}$ \\
\hline Exochorda & 2 & 232 & 0.86 & $\mathrm{R}$ \\
\hline Ficus & 3 & 877 & 0.34 & $\mathrm{R}$ \\
\hline Fuschia & 2 & 3,718 & 0.05 & NA \\
\hline Garrya & 4 & 639 & 0.63 & $\mathrm{R}$ \\
\hline Ginkgo & 2 & 270 & 0.74 & $\mathrm{R}$ \\
\hline Grevillea & 1 & 155 & 0.65 & MR \\
\hline Griselinia & 2 & 332 & 0.60 & NA \\
\hline Hedera & 10 & 1,795 & 0.56 & $\mathrm{R}$ \\
\hline Hibiscus & 11 & 1,508 & 0.73 & $\mathrm{R}$ \\
\hline Hydrangea & 52 & 6,762 & 0.77 & $\mathrm{~S}$ \\
\hline Hypericum & 3 & 453 & 0.66 & MR \\
\hline Jasminum & 10 & 1,131 & 0.88 & NA \\
\hline Kerria & 1 & 266 & 0.38 & $\mathrm{~S}$ \\
\hline Lagerstroemia & 0 & 102 & 0.00 & MR \\
\hline Laurus & 7 & 3,851 & 0.18 & NA \\
\hline Lavandula & 18 & 2,280 & 0.79 & NA \\
\hline Leptospermum & 0 & 129 & 0.00 & $\mathrm{~S}$ \\
\hline Leycesteria & 2 & 375 & 0.53 & NA \\
\hline Lonicera & 17 & 2,731 & 0.62 & $\mathrm{R}$ \\
\hline Melianthus & 1 & 121 & 0.83 & NA \\
\hline Morus & 1 & 528 & 0.19 & NA \\
\hline Myrtus & 1 & 463 & 0.22 & MR \\
\hline Nandina & 1 & 375 & 0.27 & $\mathrm{R}$ \\
\hline Nerium & 2 & 609 & 0.33 & M \\
\hline Olea & 3 & 2,526 & 0.12 & NA \\
\hline Olearia & 2 & 212 & 0.94 & NA \\
\hline Philadelphus & 5 & 852 & 0.59 & $\begin{array}{c}\mathrm{R} \\
(\text { Continued })\end{array}$ \\
\hline
\end{tabular}

${ }^{\mathrm{a}} \mathrm{AR}=$ Armillaria root rot records and $\mathrm{TE}=$ total inquiries.

${ }^{b}$ Low index $(<0.99)=$ rarely affected (resistant), Medium index $(0.99$ to 1.76$)=$ sometimes affected (moderately resistant), and High index $(>1.76)=$ frequently affected (susceptible)

${ }^{c}$ Raabe experiment (Raabe 1979, 2008): $\mathrm{R}=$ resistant, $\mathrm{MR}=$ moderately resistant, $\mathrm{S}=$ susceptible, and $\mathrm{NA}=$ not assessed.

d Based on Raabe ratings (Raabe 1979, 2008).
Table 6. (Continued)

\begin{tabular}{|c|c|c|c|c|}
\hline Host genera ${ }^{b}$ & $\mathbf{A R}$ & TE & Index & Raabe $^{c}$ \\
\hline Phlomis & 0 & 216 & 0.00 & $\mathrm{R}$ \\
\hline Phormium & 0 & 952 & 0.00 & NA \\
\hline Phygelius & 1 & 169 & 0.59 & NA \\
\hline Pieris & 11 & 1,209 & 0.91 & NA \\
\hline Pittosporum & 4 & 1,512 & 0.26 & $\mathrm{R}$ \\
\hline Protea & 1 & 126 & 0.79 & NA \\
\hline Punica & 1 & 117 & 0.85 & NA \\
\hline Pyrus & 71 & 7,464 & 0.95 & $\mathrm{R}$ \\
\hline Rhamnus & 0 & 243 & 0.00 & NA \\
\hline Ricinus & 1 & 160 & 0.63 & NA \\
\hline Rosmarinus & 7 & 941 & 0.74 & MR \\
\hline Rubus & 27 & 6,329 & 0.43 & $\mathrm{R}$ \\
\hline Salvia & 1 & 1,671 & 0.06 & NA \\
\hline Sarcococca & 0 & 850 & 0.00 & NA \\
\hline Solanum & 3 & 645 & 0.47 & NA \\
\hline Sophora & 0 & 192 & 0.00 & $\mathrm{R}$ \\
\hline Symphoricarpos & 0 & 140 & 0.00 & $\mathrm{R}$ \\
\hline Tamarix & 1 & 110 & 0.91 & NA \\
\hline Taxus & 17 & 4,028 & 0.42 & NA \\
\hline Vaccinium & 0 & 1,348 & 0.00 & NA \\
\hline Zelkova $^{\mathrm{d}}$ & 0 & 41 & 0.00 & $\mathrm{R}$ \\
\hline \multicolumn{5}{|l|}{ Medium ARR index } \\
\hline Acer & 159 & 10,926 & 1.46 & MR \\
\hline Araucaria & 7 & 633 & 1.11 & NA \\
\hline Artemisia & 2 & 183 & 1.09 & NA \\
\hline Berberis & 14 & 1,103 & 1.27 & MR \\
\hline Carpinus & 10 & 746 & 1.34 & $\mathrm{~S}$ \\
\hline Cornus & 36 & 3,611 & 1.00 & $\mathrm{R}$ \\
\hline Corylus & 7 & 665 & 1.05 & NA \\
\hline Cydonia & 3 & 269 & 1.12 & MR \\
\hline Deutzia & 5 & 318 & 1.57 & $\mathrm{~S}$ \\
\hline Embothrium & 1 & 101 & 0.99 & NA \\
\hline Eucalyptus & 28 & 1,742 & 1.61 & MR \\
\hline Euonymus & 34 & 2,247 & 1.51 & MR \\
\hline Fagus & 49 & 2,860 & 1.71 & $\mathrm{~S}$ \\
\hline Hebe & 16 & 1,413 & 1.13 & MR \\
\hline Hoheria & 2 & 126 & 1.59 & NA \\
\hline Ilex & 50 & 2,844 & 1.76 & $\mathrm{R}$ \\
\hline Juniperus & 11 & 679 & 1.62 & NA \\
\hline Lavatera & 4 & 376 & 1.06 & NA \\
\hline Magnolia & 61 & 5,881 & 1.04 & $\mathrm{R}$ \\
\hline Malus & 246 & 20,878 & 1.18 & MR \\
\hline Osmanthus & 7 & 421 & 1.66 & NA \\
\hline Paeonia & 31 & 2,514 & 1.23 & NA \\
\hline Paulownia & 5 & 375 & 1.33 & MR \\
\hline Perovskia & 2 & 133 & 1.50 & NA \\
\hline Picea & 6 & 474 & 1.27 & MR \\
\hline Pinus & 19 & 1,188 & 1.60 & MR \\
\hline Platanus & 3 & 207 & 1.45 & NA \\
\hline Populus & 7 & 576 & 1.22 & NA \\
\hline Potentilla & 4 & 341 & 1.17 & NA \\
\hline Prunus & 403 & 24,500 & 1.64 & MR \\
\hline Ribes & 52 & 4,244 & 1.23 & NA \\
\hline Rhus & 7 & 407 & 1.72 & MR \\
\hline Robinia & 26 & 1,835 & 1.42 & NA \\
\hline Rosa & 347 & 19,864 & 1.75 & NA \\
\hline Sambucus & 8 & 743 & 1.08 & $\mathrm{R}$ \\
\hline Senecio & 2 & 183 & 1.09 & NA \\
\hline Tilia & 9 & 884 & 1.02 & $\mathrm{R}$ \\
\hline Ulmus & 7 & 444 & 1.58 & $\mathrm{R}$ \\
\hline \multicolumn{5}{|l|}{ High ARR index } \\
\hline Abies & 14 & 409 & 3.42 & $\mathrm{R}$ \\
\hline Aesculus & 51 & 1,456 & 3.50 & NA \\
\hline Alnus & 5 & 214 & 2.34 & NA \\
\hline Amelanchier & 24 & 1,093 & 2.20 & NA \\
\hline Аисиьa & 17 & 823 & 2.07 & NA \\
\hline Betula & 121 & 3,367 & 3.59 & $\mathrm{~S}$ \\
\hline
\end{tabular}


Table 6. (Continued from previous page)

\begin{tabular}{|c|c|c|c|c|}
\hline Host genera ${ }^{b}$ & $\mathbf{A R}$ & TE & Index & Raabe $^{c}$ \\
\hline Buddleja & 42 & 1,233 & 3.41 & S \\
\hline Caryopteris & 3 & 169 & 1.78 & S \\
\hline Castanea & 6 & 251 & 2.39 & MR \\
\hline Ceanothus & 59 & 1,644 & 3.59 & S \\
\hline Cedrus & 65 & 756 & 8.60 & NA \\
\hline Cercidiphyllum & 14 & 226 & 6.19 & $S$ \\
\hline Cercis & 20 & 1,035 & 1.93 & $\mathrm{R}$ \\
\hline Chamaecyparis & 31 & 915 & 3.39 & MR \\
\hline Choisya & 43 & 1,429 & 3.01 & NA \\
\hline Cistus & 17 & 535 & 3.18 & NA \\
\hline Cotoneaster & 88 & 1,485 & 5.93 & S \\
\hline Crataegus & 25 & 1,111 & 2.25 & MR \\
\hline Cupressus & 30 & 773 & 3.88 & $\mathrm{R}$ \\
\hline Cytisus & 8 & 356 & 2.25 & MR \\
\hline Davidia & 5 & 247 & 2.02 & NA \\
\hline Eleagnus & 21 & 583 & 3.60 & MR \\
\hline Escallonia & 25 & 1,098 & 2.28 & S \\
\hline Eucryphia & 9 & 283 & 3.18 & NA \\
\hline Fatsia & 22 & 816 & 2.70 & NA \\
\hline Forsythia & 31 & 467 & 6.64 & NA \\
\hline Fraxinus & 27 & 972 & 2.78 & $\mathrm{R}$ \\
\hline Fremontodendron & 5 & 228 & 2.19 & $\mathrm{~S}$ \\
\hline Gleditsia & 5 & 262 & 1.91 & $\mathrm{R}$ \\
\hline Hamamelis & 28 & 747 & 3.75 & NA \\
\hline Juglans & 49 & 1,111 & 4.41 & NA \\
\hline Koelreuteria & 4 & 136 & 2.94 & MR \\
\hline Laburnum & 35 & 608 & 5.76 & $S$ \\
\hline Ligustrum & 394 & 2,375 & 16.59 & $\mathrm{~S}$ \\
\hline Liquidamber & 23 & 574 & 4.01 & $\mathrm{R}$ \\
\hline Liriodendron & 11 & 374 & 2.94 & $\mathrm{R}$ \\
\hline Mahonia & 17 & 894 & 1.90 & $\mathrm{R}$ \\
\hline Metasequoia & 9 & 111 & 8.11 & $\mathrm{R}$ \\
\hline Parrotia & 3 & 103 & 2.91 & NA \\
\hline Photinia & 76 & 3,194 & 2.38 & MR \\
\hline Physocarpus & 5 & 180 & 2.78 & NA \\
\hline Pterocarya $^{\mathrm{d}}$ & 1 & 27 & 3.70 & S \\
\hline Pyracantha & 38 & 1,747 & 2.18 & MR \\
\hline Quercus & 55 & 2,970 & 1.85 & MR \\
\hline Rhododendron & 278 & 7,842 & 3.55 & S \\
\hline Salix & 165 & 3,390 & 4.87 & NA \\
\hline Sequoia & 3 & 113 & 2.65 & $\mathrm{R}$ \\
\hline Skimmia & 22 & 1,099 & 2.00 & NA \\
\hline Sorbus & 158 & 2,311 & 6.84 & NA \\
\hline Spiraea & 8 & 443 & 1.81 & MR \\
\hline Syringa & 118 & 1,781 & 6.63 & $\mathrm{~S}$ \\
\hline Thuja & 29 & 712 & 4.07 & S \\
\hline Viburnum & 346 & 6,828 & 5.07 & $\mathrm{~S}$ \\
\hline Weigela & 31 & 497 & 6.24 & $\mathrm{~S}$ \\
\hline x Cuprocyparis & 127 & 2,057 & 6.17 & $\mathrm{R}$ \\
\hline
\end{tabular}

resistant genera. Most isolates from Eudicot genera were A. mellea. There was no significant effect of clade on species distributions, although the frequency of $A$. ostoyae was greater than expected from the Superrosid clade.

There was evidence for some differences in Armillaria sp. composition between Eudicot orders (Table 9). There were substantially more isolates of $A$. ostoyae than expected from the orders Saxifragales and Apiales, substantially more A. gallica than expected from the Malvales and Asterales, and substantially fewer A. gallica than expected from the Lamiales.

The high frequency of $A$. gallica from angiosperm hosts with unknown resistance in Table 4 was scrutinized further by examining the proportions isolated from herbaceous perennials and climbers as well as trees and shrubs (Table 10). Although the $\chi^{2}$ test was not significant $(P=0.128)$, it is interesting to note the greater number of herbaceous perennials than expected infected with A. gallica. The three examples of climbers infected with A. gallica were all Wisteria Nutt., on which there were also four instances of $A$. mellea infection.

The four isolates of $A$. ostoyae from hosts of unknown resistance were examined in more detail. All were trees or shrubs. Aralia L. $(\mathrm{AR}=2, \mathrm{TE}=67$, index $=3.0)$ is closely related to Fatsia Deane \& Planch. (index = 3.0). Disanthus Maxim. and Daphniphyllum Blume are uncommon plants (TE $=7$ and 6, respectively) in the order Saxifragales, genera of which generally occur in the high-index group. The other genus, Aronia Medik. (TE = 22), is uncommon in U.K. gardens.

\section{Discussion}

As far as we are aware, this is the first time that a diagnostic database has been used for a quantitative assessment of the relative susceptibility of host plants to a disease. Numbers of records in the RHS database were adjusted for the popularity of each host to develop an ARR index. TE was used as the measure of popularity because it was readily obtained, is likely to be a general measure of popularity not skewed by particular issues, and is the overall dataset from which disease inquiries and Armillaria identifications are made. Other possible quantitative measures could be plant sales (difficult to obtain and probably more indicative of frequency rather than value) or numbers of available cultivars or suppliers (Cubey et al. 2019) (but probably more indicative of value rather than frequency).

The $17(10 \%)$ of the 171 tree and shrub genera common in U.K. gardens that have no AR in the RHS database are likely to have adequate resistance to ARR in almost all situations. The two Buxales genera common in U.K. gardens (Buxus and Sarcococca) had very low ARR indices and are likely to be very safe choices. Monocotyledons appear to be virtually immune to Armillaria spp. and, although there are only two records in the RHS database, the work of Shearer et al. (1998) supports this conclusion because they found the monocotyledons to be the least susceptible group in coastal dunes. The 16 genera with an ARR index over 4.00 probably include most of the highest-risk planting choices. Ligustrum (privet) is a very common hedge plant in U.K. gardens and had the highest index. Infection within a single-species hedge is problematic because choice of alternative replacement plants will change its uniformity. The high degree of susceptibility of Ligustrum spp. was supported by a preliminary experiment (E. J. Beal, unpublished), where $56 \%$ of inoculated Ligustrum plants died, compared with $11 \%$ of Rosa. Ligustrum is in the Oleaceae family, which contains several very high-index genera. Gymnosperm genera were also common in the highest-index group, although some have a low or medium index, which provides some choice where the risk is high.

The three Armillaria spp. associated with ARR in our study of U.K. gardens (A. mellea, A. gallica, and A. ostoyae) are all common in North America, Europe, and Asia (Heinzelmann et al. 2019). A. mellea and A. ostoyae are highly virulent species, whereas A. gallica is less so (Rishbeth 1982). However, inoculum of both species can persist for years (Baumgartner et al. 2011), where it can pose a risk to hosts planted later in gardens, parks, orchards, and timber plantations.

The association among angiosperms between the ARR index method and the Raabe experiment suggests that the categories are relevant across regions and ecosystems. Our focus on determining the relative likelihood that a plant would be damaged or killed by Armillaria spp. was shown to be equivalent to quantitative measurement of disease in a field experiment. The Raabe categories of $\mathrm{R}, \mathrm{MR}$, and $\mathrm{S}$ were interpreted as rarely damaged, frequency infected but rarely killed, and usually killed, respectively (Raabe 1979, 2008). Similarly, the low, medium, and high ARR index categories in our study can be interpreted as $R, M R$, and S. Almost half of the angiosperm genera in each study were recorded as R (rarely affected), with only approximately $30 \%$ recorded as $\mathrm{S}$ (frequently affected), suggesting that severe dieback or death is uncommon in well-maintained plants.

In spite of not being formally published and apparently without replication of plots, the UC study appears to be the only 
experiment-based assessment of the resistance of a wide range of plants to ARR. Therefore, the results have been widely used in advising on planting choices. The similarity in ranking of angiosperm genera between our study and theirs provides evidence that each provides useful measures of the likelihood of damage from ARR across a range of planted environments.

Where the results of our study differ from those of Raabe are in the categorization of gymnosperms. Over half of the 15 gymnosperms popular in U.K. gardens were in the high-index category (S), while only 3 had a low index (R). In contrast, over half of the 15 gymnosperms in the Raabe experiment were recorded as R, while only 1 was recorded as S. It is known that ARR can be problematic in conifers in forests and woodlands (Blodgett and Worrall 1992; Greig et al. 1991; Mugala et al. 1989; Singh 1980). Redfern (1978) inoculated a range of plants with $A$. mellea sensu lato and found that the angiosperm genera Quercus L. and Fagus L. were more resistant than almost all conifers, a finding that is in agreement with the results of the present study.

The resistance of gymnosperms in the Raabe experiment suggests that the Armillaria strains present or used for inoculation were better adapted to angiosperms than to gymnosperms. The experimental site was an old orchard area known to be infested with Armillaria spp. Given the focus of the research group, it is also possible that isolates used for inoculation were adapted to angiosperms. Shaw (1977) tested the pathogenicity of Armillaria isolates from pine and angiosperm trees to pine seedlings, finding that all pine isolates and none of the hardwood isolates were highly pathogenic to pines. It is possible that the different strains represented different modern day species of Armillaria.

Identifying trends in ARR resistance at higher taxonomic levels would help to predict the status of genera where data are lacking. In our study, genera in the orders Myrtales and Ericales were particularly likely to be resistant, while the orders Saxifragales and Fagales, along with the Lamiales family Oleaceae, contained many high-index genera. Shearer et al. (1998) compared families for their relative susceptibility to ARR in coastal dunes in Australia. There was limited overlap with our study because Australian plant families are not particularly well represented in U.K. gardens. However, as in our study, Shearer et al. (1998) reported that monocotyledons were almost never killed.

Table 7. Armillaria root rot (ARR) and Armillaria spp. records on different Prunus types and species

\begin{tabular}{|c|c|c|c|c|c|c|}
\hline \multirow[b]{3}{*}{ Species } & \multirow{2}{*}{\multicolumn{3}{|c|}{ Disease records $^{\mathbf{a}}$}} & \multicolumn{3}{|c|}{$\begin{array}{c}\text { Percentage of Armillaria spp. } \\
\text { (number) }\end{array}$} \\
\hline & & & & \multirow{2}{*}{$\begin{array}{c}\text { Armillaria } \\
\text { mellea }\end{array}$} & \multirow{2}{*}{$\begin{array}{c}A . \\
\text { gallica }\end{array}$} & \multirow{2}{*}{$\begin{array}{c}A . \\
\text { ostoyae }\end{array}$} \\
\hline & $\mathbf{A R}$ & TE & Index & & & \\
\hline Edible (total) & 86 & 8,497 & 1.01 & $72.7(8)$ & $27.3(3)$ & 0 \\
\hline $\begin{array}{l}\text { Apricot (Prunus } \\
\text { armeniaca) }\end{array}$ & 1 & 616 & 0.16 & 1 & 0 & 0 \\
\hline Cherry - fruit ${ }^{b}$ & 10 & 454 & 2.20 & 1 & 1 & 0 \\
\hline $\begin{array}{l}\text { Plum } \\
\quad(P . \text { domestica })\end{array}$ & 60 & 5,784 & 1.04 & 5 & 2 & 0 \\
\hline $\begin{array}{l}\text { Damson } \\
\quad(P . \text { institia })\end{array}$ & 8 & 628 & 1.27 & 1 & 0 & 0 \\
\hline $\begin{array}{l}\text { Peach, nectarine } \\
\quad(P . \text { persica })\end{array}$ & 7 & 1,015 & 0.69 & 0 & 0 & 0 \\
\hline Ornamental (total) & 152 & 9,258 & 1.64 & $75.0(12)$ & $18.8(3)$ & $6.2(1)$ \\
\hline $\begin{array}{r}\text { Flowering } \\
\text { Prunus }^{\mathrm{b}}\end{array}$ & 96 & 4,935 & 1.95 & 8 & 2 & 1 \\
\hline $\begin{array}{l}\text { Cherry laurel } \\
\text { (P. laurocerasus) }\end{array}$ & 41 & 3,749 & 1.09 & 3 & 2 & 0 \\
\hline $\begin{array}{l}\text { Portuguese laurel } \\
\quad(P . \text { lusitanica })\end{array}$ & 15 & 745 & 2.01 & 1 & 1 & 0 \\
\hline Unspecified & 165 & 6,574 & 2.51 & 93.3 (14) & 0 & $6.3(1)$ \\
\hline All Prunus spp. & 403 & 24,500 & 1.64 & $77.3(34)$ & $18.2(8)$ & $4.5(2)$ \\
\hline
\end{tabular}

Identifying differences in resistance to ARR within genera grown in gardens would be impractical in most cases, given the enormous numbers of species, subspecies, crosses, and cultivars grown in gardens. There are currently 274 cultivars within 27 species and 11 subspecies, as well as several interspecific crosses of Cornus spp. and 125 species, 9 subspecies, 25 crosses, and 106 named cultivars of Quercus available in the United Kingdom (Cubey et al. 2019). It was possible to examine RHS records within the genus Prunus, which has 24,500 inquiries and $403 \mathrm{AR}$, and is often recorded by species or fruit type. Prunus has a medium ARR index at the genus level and also when species are grouped by ornamental or edible use, suggesting that situation or use in a garden has no particular effect on the likelihood of damage from ARR. Some differences in resistance categories were, however, identified. Of the two "laurel" types, the ARR index of $P$. lusitanica was considerably greater than that of $P$. laurocerasus, while cherry was the only type of edible Prunus sp. in the high-index category.

The interconnected roots of hedges provide the perfect conditions for spread of the virulent species A. mellea and A. ostoyae, which produce only sparse rhizomorphs (Rishbeth 1982). Those of A. mellea seldom extend more than $5 \mathrm{~cm}$ from infected roots, although they may be abundant at the base of diseased trees (Rishbeth 1982). Ligustrum (privet) is a popular hedge plant in the United Kingdom and had the highest ARR index in our study. Almost all (97\%) records on Ligustrum were of A. mellea, compared with $83 \%$ across all genera. Ligustrum spp. are resilient plants and are able to tolerate stressful conditions well (Dirr 2011), with Ligustrum vulgare L. (the species most common in U.K. hedges) being known as an invasive plant in the United States (Ehrenfeld 2008). This may also contribute to

Table 8. Armillaria root rot (ARR) index for host plant taxonomic groups above genus level ${ }^{\mathrm{a}}$

\begin{tabular}{|c|c|c|c|c|c|c|}
\hline \multirow[b]{2}{*}{ Groups } & \multirow{2}{*}{$\begin{array}{c}\text { Number in } \\
\text { group }\end{array}$} & \multicolumn{5}{|c|}{ ARR index } \\
\hline & & Min & LQ & Med & UQ & Max \\
\hline Gymnosperms & 15 & 0.4 & 1.1 & 2.7 & 4.1 & 8.6 \\
\hline Angiosperms & 155 & 0 & 0.4 & 1 & 1.9 & 16.6 \\
\hline \multicolumn{7}{|l|}{ Angiosperm clades } \\
\hline Magnolids & 4 & 0 & 0.1 & 0.6 & 2.0 & 2.9 \\
\hline Monocotyldeons & 4 & 0 & 0 & 0.1 & 0.1 & 0.1 \\
\hline Eudicots & 147 & 0 & 0.6 & 1.1 & 2.0 & 16.6 \\
\hline \multicolumn{7}{|l|}{ Eudicot clades } \\
\hline Eudicots & 10 & 0 & 0.3 & 0.8 & 1.3 & 1.9 \\
\hline Superrosids & 6 & 1.2 & 2.1 & 3.3 & 3.9 & 6.2 \\
\hline Rosids & 73 & 0 & 0.7 & 1.4 & 2.2 & 6.8 \\
\hline Asterids & 55 & 0 & 0.4 & 0.8 & 1.8 & 16.6 \\
\hline \multicolumn{7}{|l|}{ Eudicot orders } \\
\hline Saxifragales & 6 & 1.2 & 2.1 & 3.3 & 3.9 & 6.2 \\
\hline Fabales & 9 & 0 & 0.7 & 1.4 & 1.9 & 5.8 \\
\hline Rosales & 25 & 0 & 0.9 & 1.6 & 2.3 & 6.8 \\
\hline Fagales & 8 & 1.1 & 1.5 & 2.1 & 3.0 & 4.4 \\
\hline Malpighiales & 4 & 0.6 & 0.6 & 0.9 & 3.0 & 4.9 \\
\hline Myrtales & 7 & 0 & 0.1 & 0.2 & 1.2 & 1.6 \\
\hline Sapindales & 8 & 0 & 1.6 & 1.9 & 3.0 & 3.5 \\
\hline Malvales & 9 & 0.2 & 0.6 & 1.0 & 1.8 & 3.2 \\
\hline Cornales & 6 & 0 & 0.6 & 0.8 & 1.6 & 2 \\
\hline Ericales & 7 & 0 & 0.2 & 0.8 & 0.9 & 3.5 \\
\hline Lamiales & 21 & 0 & 0.2 & 0.9 & 1.8 & 16.6 \\
\hline Dipsacales & 7 & 0 & 0.6 & 0.7 & 3.1 & 6.2 \\
\hline \multicolumn{7}{|l|}{ Rosales families } \\
\hline Rosaceae & 19 & 0.4 & 0.9 & 1.6 & 2.2 & 6.8 \\
\hline Other & 6 & 0 & 0.2 & 1.0 & 3.6 & 3.6 \\
\hline \multicolumn{7}{|l|}{ Lamiales families } \\
\hline Oleaceae & 7 & 0.1 & 1.3 & 2.8 & 6.6 & 16.6 \\
\hline Other & 14 & 0 & 0.1 & 0.6 & 1.3 & 3.4 \\
\hline
\end{tabular}

${ }^{\mathrm{a}} \mathrm{Min}=$ minimum, $\mathrm{LQ}=$ lower quartile, $\mathrm{Med}=$ median, $\mathrm{UQ}=$ upper quartile, and Max = maximum. Restricted to $100+$ total Royal Horticultural Society inquiries with at least four genera per group. 
the low proportion of A. gallica on Ligustrum (3\%, compared with $15 \%$ across all general). Observation of Ligustrum spp. in the United Kingdom often shows a pattern of sudden death of plants in sequence along an apparently otherwise healthy hedge (unpublished observations).

The RHS dataset includes records of Armillaria spp. on nonwoody hosts such as herbaceous perennials. In spite of being minor hosts, they may aid in the survival or spread of the fungus in a garden. In an earlier examination of RHS records (1994 to 1998), herbaceous perennials contributed approximately $1.5 \%$ of total AR (RobinsonBax and Fox 2002). Robinson-Bax and Fox (2002) and Ford et al. (2016) tested a range of garden herbaceous plants in inoculated experiments. They confirmed that several herbaceous garden plants can support A. mellea in the absence of trees or shrubs and suggested that this should be considered when a control program is initiated in parks and gardens where herbaceous hosts as well as woody hosts may both be present.
Both resistance and tolerance provide useful tools for ARR management (Heinzelmann et al. 2019). Very low-index hosts may be both resistant and tolerant, whereas very high-index plants may be neither. Rapid dieback or death of infected plants often follows the onset of hot, dry weather, suggesting that tolerance to ARR could be associated with drought tolerance. Douglas-fir lines with greater

Table 10. Proportions of different Armillaria spp. isolated from angiosperm trees and shrubs, other perennials, or climbers ${ }^{\mathrm{a}}$

\begin{tabular}{lccc}
\hline & \multicolumn{3}{c}{ Percentage in category (number) } \\
\cline { 2 - 4 } Host & Armillaria mellea & A. gallica & A. ostoyae \\
\hline Tree or shrub & $82.8(506)$ & $15.1(92)$ & $2.1(13)$ \\
Other perennial & $58.3(7)$ & $41.7(5)$ & $0(0)$ \\
Climber & $66.7(6)$ & $33.3(3)$ & $0(0)$ \\
\hline
\end{tabular}

${ }^{a}$ For $\chi^{2}, 4$ degrees of freedom, $\chi^{2}=7.14, P=0.128$.

Table 9. Distribution of index (Royal Horticultural Society) categories and Armillaria isolations in different host taxonomic groups ${ }^{\mathrm{a}}$

\begin{tabular}{|c|c|c|c|c|c|c|}
\hline \multirow[b]{3}{*}{ Hosts } & \multicolumn{3}{|c|}{ Index category } & \multicolumn{3}{|c|}{ Armillaria spp. isolations } \\
\hline & \multicolumn{3}{|c|}{ Percentage of group (number) } & \multicolumn{3}{|c|}{ Percentage of isolates in each order (number) } \\
\hline & Low & Medium & High & Armillaria mellea & A. gallica & A. ostoyae \\
\hline Gymnosperms & $20.0(3)^{\mathrm{b}}$ & $26.7(4)$ & $53.3(8)^{\mathrm{c}}$ & $90.0(45)$ & $8.0(4)$ & $2.0(1)$ \\
\hline Angiosperms & $47.7(74)$ & $21.3(33)$ & $31.0(48)$ & $82.7(520)$ & $15.3(96)$ & $2.1(13)$ \\
\hline$x^{2}$ & \multicolumn{3}{|c|}{$4 \mathrm{df}, \chi^{2}=9.0, P=0.06$} & \multicolumn{3}{|c|}{$2 \mathrm{df}, \chi^{2}=2.3, P=0.32$} \\
\hline Magnolids & $50.0(2)$ & $25.0(1)$ & $25.0(1)$ & $100(10)$ & 0 & 0 \\
\hline Monocotyldeons & $100(4)^{\mathrm{c}}$ & $0.0(0)$ & $0.0(0)$ & $50.0(1)$ & $50.0(1)$ & 0 \\
\hline Eudicots & $46.3(68)$ & $21.8(32)$ & $32.0(47)$ & $82.6(509)$ & $15.4(95)$ & $2.1(13)$ \\
\hline$\chi^{2}$ & \multicolumn{3}{|c|}{$4 \mathrm{df}, \chi^{2}=6,1, P=0.19$} & \multicolumn{3}{|c|}{$4 \mathrm{df}, \chi^{2}=5 . .2, P=0.27$} \\
\hline \multicolumn{7}{|l|}{ Eudicots } \\
\hline Eudicots & $70.0(7)$ & $20.0(2)$ & $10.0(1)$ & $83.3(5)$ & $16.7(1)$ & 0 \\
\hline Superrosids & $0.0(0)^{\mathrm{b}}$ & $33.3(2)$ & $66.7(4)^{\mathrm{c}}$ & $65.4(17)$ & $23.1(6)$ & $11.5(2)^{\mathrm{c}}$ \\
\hline Rosids & $38.4(28)$ & $24.7(18)$ & $37.0(27)$ & $82.0(278)$ & $15.9(54)$ & $2.1(7)$ \\
\hline Superasterids & $66.7(2)$ & $0.0(0)$ & $33.3(1)$ & $100(2)$ & 0 & 0 \\
\hline Asterids & $56.4(31)$ & $18.2(10)$ & $25.5(14)$ & $84.8(207)$ & $13.9(34)$ & $1.2(3)$ \\
\hline$\chi^{2}$ & \multicolumn{3}{|c|}{$8 \mathrm{df}, \chi^{2}=16.4, P=0.04$} & \multicolumn{3}{|c|}{$8 \mathrm{df}, \chi^{2}=6.7, P=0.57$} \\
\hline \multicolumn{7}{|l|}{ Eudicot orders } \\
\hline Ranunculales & $50.0(2)$ & $25.0(1)$ & $25.0(1)$ & $80.0(4)$ & $20.0(1)$ & 0 \\
\hline Proteales & $75.0(3)$ & $25.0(1)$ & $0.0(0)$ & $100(1)$ & 0 & 0 \\
\hline Buxales & $100(2)$ & $0.0(0)$ & $0.0(0)$ & $\ldots$ & $\ldots$ & $\ldots$ \\
\hline Saxifragales & $0.0(0)^{\mathrm{b}}$ & $33.3(2)$ & $66.7(4)^{\mathrm{c}}$ & $65.4(17)$ & $23.1(6)$ & $11.5(3)^{\mathrm{c}}$ \\
\hline Fabales & $44.1(4)$ & $11.1(1)$ & $44.1(4)$ & $77.8(21)$ & $22.2(6)$ & 0 \\
\hline Rosales & $36.0(9)$ & $24.0(6)$ & $40.0(10)$ & $85.8(163)$ & $11.6(22)$ & $2.6(5)$ \\
\hline Fagales & $0.0(0)^{\mathrm{b}}$ & $37.5(3)$ & $62.5(5)^{\mathrm{c}}$ & $77.8(28)$ & $19.4(7)$ & $2.8(1)$ \\
\hline Vitales & $\ldots$ & $\ldots$ & $\ldots$ & $100(1)$ & 0 & 0 \\
\hline Celstales & $0.0(0)$ & $100(1)$ & $0.0(0)$ & $75.0(6)$ & $25.0(2)$ & 0 \\
\hline Oxalidales & $0.0(0)$ & $0.0(0)$ & $100(1)$ & $100(2)$ & 0 & 0 \\
\hline Malpighiales & $50.0(2)$ & $25.0(1)$ & $25.0(1)$ & 86.7 (13) & $13.3(2)$ & 0 \\
\hline Geraniales & $100(1)$ & $0.0(0)$ & $0.0(0)$ & $100(1)$ & 0 & 0 \\
\hline Myrtales & $85.7(6)^{\mathrm{c}}$ & $14.3(1)$ & $0.0(0)^{\mathrm{b}}$ & $100(3)$ & 0 & 0 \\
\hline Crossomateles & $\ldots$ & $\ldots$ & $\ldots$ & $100(2)$ & 0 & 0 \\
\hline Sapindales & $25.0(2)$ & $25.0(2)$ & $50.0(4)$ & $81.6(31)$ & $15.8(6)$ & $2.6(1)$ \\
\hline Malvales & $44.4(4)$ & $33.3(3)$ & $22.2(2)$ & $43.8(7)^{\mathrm{b}}$ & $56.3(9)^{\mathrm{c}}$ & $0^{\mathrm{b}}$ \\
\hline Caryophyllales & $66.7(2)$ & $0.0(0)$ & $33.3(1)$ & $100(2)$ & 0 & 0 \\
\hline Cornales & $50.0(3)$ & $33.3(2)$ & $16.7(1)$ & $83.3(10)$ & $16.7(2)$ & 0 \\
\hline Ericales & $85.7(6)^{c}$ & $0.0(0)$ & $14.3(1)$ & $75(27)$ & $22(8)$ & $3(1)$ \\
\hline Garryales & $50.0(1)$ & $0.0(0)$ & $50.0(1)$ & 0 & $100(1)$ & 0 \\
\hline Gentianales & $100(2)$ & $0.0(0)$ & $0.0(0)$ & $100(2)$ & 0 & 0 \\
\hline Solanales & $66.7(2)$ & $0.0(0)$ & $33.3(1)$ & 0 & $100(1)$ & 0 \\
\hline Lamiales & $52.4(11)$ & $19.0(4)$ & $28.6(6)$ & $93.9(93)$ & $6.1(6)^{b}$ & 0 \\
\hline Aquifoliales & $0.0(0)$ & $100(1)$ & $0.0(0)$ & $88.9(8)$ & $11.1(1)$ & 0 \\
\hline Asterales & $33.3(1)$ & $66.7(2)$ & $0.0(0)$ & $33.3(1)$ & $66.6(2)^{\mathrm{c}}$ & 0 \\
\hline Escalloniales & $0.0(0)$ & $0.0(0)$ & $100(1)$ & $100(8)$ & 0 & 0 \\
\hline Dipsacales & $57.1(4)$ & $14.3(1)$ & $28.6(2)$ & $80.3(53)$ & $18.2(12)$ & $1.5(1)$ \\
\hline Apiales & $66.7(2)$ & $0.0(0)$ & $33.3(1)$ & $71.4(5)$ & $14.3(1)$ & $14.3(1)^{\mathrm{c}}$ \\
\hline$\chi^{2}$ & \multicolumn{3}{|c|}{$40 \mathrm{df}, \chi^{2}=55.0, P=0.058$} & \multicolumn{3}{|c|}{$52 \mathrm{df}, \chi^{2}=66.3, P=0.087$} \\
\hline
\end{tabular}

\footnotetext{
a Index categories: Low $(<0.99)$, Medium $(0.99$ to 1.76$)$, and High $(>1.76)$; $\mathrm{df}=$ degrees of freedom.

b Substantially fewer than expected.

${ }^{\mathrm{c}}$ Substantially more than expected.
} 
levels of ARR resistance also had a higher drought tolerance (Cruickshank and Filipescu 2017).

A. mellea affected both angiosperms and gymnosperms in our study and was the most common species isolated from plants, regardless of their susceptibility to the disease. In contrast, A. ostoyae was rare, even on conifers. Contrary to previous reports suggesting that $A$. ostoyae has a host preference for conifers (Blodgett and Worrall 1992; Rishbeth 1982), only 1 of the 14 isolates in our study was from a conifer. The low abundance of $A$. ostoyae in our survey is likely to reflect its poor suitability for garden environments.

Rishbeth (1982) suggested that the capacity of A. gallica to produce freely spreading rhizomorphs probably contributes to the very large size of some of its foci and accounts for the frequency with which it invades severely weakened trees. The higher proportion of A. gallica on perennials in our study may be due to it being an opportunistic pathogen, possibly colonizing nonwoody perennials that have been weakened or stressed. The trend for it to occur on resistant hosts might also be associated with plants under stress. Alternatively, it is possible that $A$. gallica is more common in gardens than our survey would suggest, because most inquiries are based on severe aboveground symptoms on plants. Further work would be required to determine whether there is value in trying to eliminate $A$. gallica or to manage its influence by minimizing the abiotic stress on potential hosts.

Climatic maladaptation increases the predisposition of a host to ARR because of chronic stress (Heinzelmann et al. 2019) and, therefore, it follows that planting choice in gardens should take into account the degree of adaptation of a host to the particular climate. Exotic plants (grown outside of their natural range) are nonetheless common in gardens. Although many of these are well suited to the climate they are grown in, they may encounter abiotic or biotic stresses that are less common in their native habitat, which could increase their susceptibility to ARR. Choosing the right plant in the right place may reduce the risk that a plant that has been exposed to Armillaria spp. will exhibit aerial symptoms.

\section{Acknowledgments}

We thank RHS members for the provision of sample material and H. Latham for assistance with Armillaria spp. identification. The RHS is a registered charity, number 222879/SC038262.

\section{Literature Cited}

Anderson, J. B., and Ullrich, R. C. 1979. Biological species of Armillaria mellea in North America. Mycologia 71:402-414.

Angiosperm Phylogeny Group. 2016. An update of the Angiosperm Phylogeny Group classification for the orders and families of flowering plants: APG IV. Bot. J. Linn. Soc. 181:1-20.

Baumgartner, K., Coetzee, M. P. A., and Hoffmeister, D. 2011. Secrets of the subterranean pathosystem of Armillaria. Mol. Plant Pathol. 12:515-534.

Baumgartner, K., and Rizzo, D. M. 2001. Ecology of Armillaria spp. in mixedhardwood forests of California. Plant Dis. 85:947-951.

Blodgett, J. T., and Worrall, J. J. 1992. Distributions and hosts of Armillaria species in New York. Plant Dis. 76:166-170.

Coetzee, M. P. A., Wingfield, B. D., Harrington, T. C., Steimel, O., Coutinho, T. A., and Wingfield, M. J. 2001. The root rot fungus Armillaria mellea introduced into South Africa by early Dutch settlers. Mol. Ecol. 10:387-396.

Coetzee M. P. A., Wingfield, B. D., and Wingfield, M. J. 2018. Armillaria root-rot pathogens: Species boundaries and global distribution. Pathogens 7:e83.

Cruickshank, M. G., and Filipescu, C. N. 2017. The interactive effect of root disease and climate on wood properties in halfsibling Douglas-fir families. For. Ecol. Manage. 392:58-67.

Cubey, J., Edwards, D., Konyves, K., Lancaster, N., and Marshall, R., eds. 2019. Plant Finder 2019. Royal Horticultural Society, London, U.K.

Denman, S., Barrett, G., Kirk, S. A., McDonald, J. E., and Coetzee, M. P. A. 2016. Identification of Armillaria species on declined oak in Britain: Implications for oak health. Forestry 90:148-161.

Dickens, J. S. W., ed. 1985. Leaflet 500: Armillaria Root Rot. Revised by R. G. Strouts. Ministry of Agriculture, Fisheries and Food, Alnwick, U.K.
Dirr, M. 2011. Dirr's Encyclopedia of Trees \& Shrubs. Timber Press, Portland, OR, U.S.A. \& London, England, U.K.

Drakulic, J., Gorton, C., Perez-Sierra, A., Clover, G., and Beal, L. 2017. Associations between Armillaria species and host plants in U.K. gardens. Plant Dis. 101:1903-1909.

Ehrenfeld, J. G. 2008. Exotic invasive species in urban wetlands: Environmental correlates and implications for wetland management. J. Appl. Ecol. 45: 1160-1169.

Ford, K. L., Henricot, B., Baumgartner, K., Bailey, A. M., and Foster, G. D. 2016 A faster inoculation assay for Armillaria using herbaceous plants. J. Hortic. Sci. Biotechnol. 92:39-47.

Gregory, S. C., Rishbeth, J., and Shaw, C. G., III. 1991. Pathogenicity and virulence. Pages 76-87 in: Armillaria Root Disease Agriculture Handbook No. 691. C. G. Shaw, III and G. S. Kile, eds. United States Department of Agriculture Forest Service, Washington, DC, U.S.A.

Greig, B. J. W., Gregory, S. C., and Strouts, R. G. 1991. Honey Fungus. Forestry Commission Bulletin 100. Forestry Commission, London, U.K.

Guillaumin, J.-J., Mohammed, C., Anselmi, N., Courtecuisse, R., Gregory, S. C., Holdenrieder, O., Intini, M., Lung, B., Marxmüller, H., Morrison, D., Rishbeth, J., Termorshuizen, A. J., Tirró, A., and van Dam, B. 1993. Geographical distribution and ecology of the Armillaria species in Western Europe. Eur. J. Forest Pathol. 23:321-341.

Hawes, C., Haughton, A. J., Osborne, J. L., Roy, D. B., Clark, S. J., Perry, J. N., Rothery, P., Bohan, D. A., Brooks, D. R., Champion, G. T., Dewar, A. M., Heard, M. S., Woiwod, I. P., Daniels, R. E., Young, M. W., Parish, A. M., Scott, R. J., Firbank, L. G., and Squire, G. R. 2003. Responses of plants and invertebrate trophic groups to contrasting herbicide regimes in the farm scale evaluations of genetically modified herbicide-tolerant crops. Philos. Trans. R. Soc. Lond. B Biol. Sci. 358:1899-1913.

Heinzelmann, R., Dutech, C., Tsykun, T., Labbe, F., Soularue, J., and Prospero, S. 2019. Latest advances and future perspectives in Armillaria research. Can. J. Plant Pathol. 41:1-23.

Korhonen, K. 1978. Interfertility and clonal size in the Armillariella mellea complex. Karstenia 18:31-42.

Moore, W. C. 1959. Pages 57-61 in: British Parasitic Fungi. Cambridge University Press, Cambridge, U.K.

Mugala, M. S., Blenis, P. V., Hiratsuka, Y., and Mallett, K. I. 1989. Infection of lodgepole pine and white spruce by Alberta isolates of Armillaria. Can. J. For. Res. 19:685-689.

Mulholland, V., MacAskill, G. A., Laue, B. E., Steele, H., Kenyon, D., and Green, S. 2012. Development and verification of a diagnostic assay based on EF-1 $\alpha$ for the identification of Armillaria species in Northern Europe. For. Pathol. 42: 229-238.

Perry, J. N. 1982. Fitting split-lines to ecological data. Ecol. Entomol. 7:421-435.

Raabe, R. D. 1962. Host list of the root rot fungus, Armillaria mellea. Hilgardia 33 $25-88$

Raabe, R. D. 1966. Testing plants for resistance to oak root fungus. Calif. Agric. 20:12-13.

Raabe, R. D. 1979. Resistance or susceptibility of certain plants to Armillaria root rot, Leaflet 2591. University of California Division of Agricultural Science, Berkeley, CA, U.S.A.

Raabe, R. D. 2008. Plants Resistant or Susceptible to Armillaria mellea, the Oak Root Fungus. University of California, Berkeley. https://mastergardeners.org/ pdf/Armillarialist-2008-06-16.pdf and http://mgsantaclara.ucanr.edu/files/ 244383.pdf

Redfern, D. B. 1978. Infection by Armillaria mellea and some factors affecting host resistance and the severity of disease. Forestry 51:121-135.

Rishbeth, J. 1982. Species of Armillaria in Southern England. Plant Pathol. 31 9-17.

Robinson-Bax, C., and Fox, R. T. V. 2002. Root rots of herbaceous plants caused by Armillaria mellea. Mycologist 16:21-22.

Shaw, C. G. 1977. Armillaria isolates from pine and hardwoods differ in pathogenicity to pine seedlings. Plant Dis. Rep. 61:416-418.

Shearer, B. L., Crane, C. E., Fairman, R. G., and Grant, M. J. 1998. Susceptibility of plant species in coastal dune vegetation of South-western Australia to killing by Armillaria luteobubalina. Aust. J. Bot. 46:321-334.

Singh, P. 1980. Armillaria root rot: Artificial inoculation and development of the disease in greenhouse. Eur. J. Forest Pathol. 10:420-431.

Travadon, R., Smith, M. E., Fujiyoshi, P., Douhan, G. W., Rizzo, D. M., and Baumgartner, K. 2012. Inferring dispersal patterns of the generalist root fungus Armillaria mellea. New Phytol. 193:959-969.

Tsopelas, P. 1999. Distribution and ecology of Armillaria species in Greece. Eur. J. Forest Pathol. 29:103-116.

VSN International. 2013. GenStat for Windows, 16th ed. VSN International, Hemel Hempstead, U.K. 